\title{
EDUCAÇÃO E VALORES NO MUNDO CONTEMPORÂNEO
}

\author{
Pedro Goergen ${ }^{*}$
}

RESUMO: O artigo aborda um dos mais destacados e controversos temas do homem e da sociedade contemporâneos: a fundamentação dos valores morais e a educação moral. Diante das graves implicaçōes que os rumos da ciência e tecnologia têm para áreas vitais das pessoas, da sociedade e da própria natureza, a ética tornou-se preocupação universal de grande urgência. Partindo de uma definição de conceito de valor, o autor expóe, desde um ponto de vista histórico as vertentes individualista, social, pós-moderna e teórico-crítica, para concluir com algumas observações sobre a formação do sujeito moral. Todo o trabalho está perpassado pelo olhar da educação.

Palavras-chave: Valores. Ética. Moral. Educação moral. Sujeito moral. Agir comunicativo.

\section{EDUCATION AND VALUES IN THE CONTEMPORARY WORLD}

ABSTRACT: This paper explores one of the most highlighted and controversial theme of contemporary men and society: the foundations of moral values and moral education. Faced with the serious implications of the scientific and technological trends on the vital areas of people, society and nature itself, ethic has become a universal, very pressing issue. From a historical point of view, and based on a definition of the concept of value, the author exposes its individualistic, social, post-modern and theoretical-critical aspects. He then concludes with some observations on the formulation of the moral subject. The whole work is impregnated with the views of education.

Key words: Values. Ethic. Moral. Moral education. Moral subject. Communicative action.

Professor titular da Universidade de Sorocaba (UNISO) e professor titular aposentado da Universidade Estadual de Campinas (UNICAMP).E-mail: gorgen@unicamp.br

Educ. Soc., Campinas, vol. 26, n. 92, p. 983-1011, Especial - Out. 2005 


\section{Introdução}

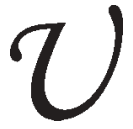

$\mathrm{m}$ tema tão amplo e controverso quanto educação e valores só pode ser tratado de forma parcial e lacunar nos limites de um breve artigo. Uma abordagem mais sistemática e abrangente exigiria um espaço muito mais amplo como demonstra a farta bibliografia que existe a respeito do tema. Embora seja sempre uma aventura arriscada enveredar pelo campo da ética e da moral, é uma aventura dia a dia mais urgente e necessária. Particularmente, desde a idade moderna, quando Deus deixou de ser tanto o fundamento indiscutível das normas morais quanto o ponto de referência para as decisões morais do homem, a busca incessante de novas formas de legitimação tornou-se preocupação constante de filósofos, psicólogos, sociólogos, antropólogos, economistas, politicólogos e pedagogos. Hoje, esta preocupação espraia-se por todas as áreas do saber incluindo a comunicação, a genética, a biologia, a medicina etc. Podemos dizer que a preocupação ética tornou-se universal e está presente em todos os âmbitos da vida humana.

Tal universalização deve-se ao próprio desenvolvimento da racionalidade moderna que, ao estabelecer uma relação intrínseca entre as dimensões teóricas (científicas) e as dimensões práticas (éticas), fez com que ambas sempre estejam presentes na própria matriz de qualquer conhecimento. Os debates contemporâneos sobre a relação do conhecimento científico e as possibilidades técnicas de seu uso para manipulação da vida nos mostram que a preocupação ética é coetânea ao próprio pensamento. Mesmo assim, como diz Cortina (2003, p. 18), "embora a ética esteja na moda e todo mundo fale dela, ninguém chega realmente a acreditar que ela seja importante, e mesmo essencial para viver". Há uma curiosa ambigüidade entre o discurso ético que se dissemina e ocupa todos os espaços e a efetiva importância que se dá à ética no campo prático.

Embora educação e ética estejam relacionadas desde os primórdios de nossa civilização, esta discrepância entre a teoria e a prática também sempre foi muito nítida. Ao mesmo tempo em que todos reconhecem a importância da relação entre ética/moral e educação, tanto nas famílias, nas instituições sociais, na mídia e também na própria escola, o tratamento dispensado à ética denota antes menosprezo que apreço. No caso da escola, por exemplo, certamente não há diretor, nem orientador ou professor que não se digam comprometidos com a relevância da ética para o agir educativo. Mesmo assim, ao primeiro olhar sobre a estrutura 
curricular e o quotidiano escolar, constatamos que a ética ocupa um lugar bastante singelo, muitas vezes restrito a um recorte disciplinar ou, quando muito, a uma atividade transversal.

$\mathrm{Na}$ raiz desse aparente ou real desinteresse há, a meu modo dever, uma questão muito concreta: o que pode ou deve a escola fazer, em termos de educação ética, no contexto de uma sociedade democrática e pluralista que não dispõe de valores em torno dos quais haja consenso e que, ademais, não está disposta a inculcar nos jovens valores ou formas de comportamento que não são partilhados por todos. A sociedade multicultural, fortalecida pelo curso da globalização e da mobilidade social, em que partilham espaço múltiplas visões de homem, de vida e de mundo, veio agravar ainda mais este desnorteamento da educação e da escola. Há tantas disparidades que a todo o momento nos encontramos à porta do relativismo. Não só as diferenças culturais de nível macro, como as existentes entre o primeiro e o terceiro mundos, mas também as de nível micro, existentes no interior das sociedades entre os vários grupos sociais, culturais e étnicos exigem formas diferenciadas de educação ética. A escola que deve servir e respeitar a todos encontra-se ante um desafio de difícil solução.

Penso que na história da filosofia prática (ética) há duas vertentes que determinam desde a raiz o comportamento moral do homem. Tratase, de um lado, da vertente que privilegia o indivíduo e, de outro, da que privilegia a sociedade. Nas páginas que se seguem, gostaria de discutir um pouco esta relação entre estas duas dimensões da ética e da moral desde o recorte dos valores.

Como primeiro passo, julguei necessário um aclaramento do próprio conceito de valor. A seguir, destaco alguns momentos históricos que privilegiam o viés individual e, na seqüência, faço o mesmo, porém, dando destaque a autores que defendem a sociedade como fundamento ético. Nos itens quatro e cinco em rápidos traços, chamo a atenção para a concepção de valor da vertente pós-moderna e teórico-crítica. Por último, faço algumas considerações sobre a formação do sujeito moral com apoio em Josep Puig.

\section{Definição do conceito valor}

O estudo da problemática dos valores é muitas vezes denominado de axiologia, que é um termo derivado do grego axia e que significa "va- 
lor". Num trabalho de natureza filosófica sobre valores é conveniente, antes de tudo, esclarecer, pelo menos em termos gerais, o sentido do conceito de valor, apontando também algumas das dificuldades que lhe são inerentes. De início, podemos adiantar que não há um só, mas muitos sentidos para o termo valor como veremos a seguir, assim enunciados por André Lalande (1999) no seu Vocabulário técnico e crítico da Filosofia.

a) característica das coisas que consiste em serem elas mais ou menos estimadas ou desejadas por um sujeito ou, mais comumente, por um grupo de sujeitos determinados. Este é um significado subjetivo.

b) Característica das coisas que consiste em merecerem elas maior ou menor estima. Este é um significado objetivo.

c) Característica das coisas que consiste em elas satisfazerem um certo fim. Trata-se do caráter objetivo/hipotético.

d) Característica de coisas que consiste no fato de, em determinado grupo social e em determinado momento, serem trocadas por uma quantidade determinada de uma mercadoria tomada como unidade.

e) Preço que se estima do ponto de vista normativo deva ser pago por um determinado objeto ou serviço (justo valor).

f) A significação não só literal, mas efetiva e implícita que possuem uma palavra ou expressão (Lalande, 1999, verbete 'valores').

Para se ter uma noção do desenvolvimento histórico da concepção de valor e de seus diferentes significados é útil recorrer também ao Dicionário de Filosofia de Nicola Abbagnano (1970). Desde a Antiguidade, o termo foi usado para designar a utilidade ou o preço de bens materiais ou o mérito de pessoas. Este significado não tem valor filosófico porque não gerou problemas filosóficos. $\mathrm{O}$ uso filosófico só começa quando o seu significado é generalizado para qualquer objeto de preferência ou de escolha. Isto aconteceu pela primeira vez com os estóicos, ${ }^{1}$ os quais introduziram o termo no domínio da ética e chamaram valor os objetos de escolhas morais. Os estóicos entendem o bem como algo subjetivo, como um objeto de escolha particular (preferência). Distinguiam entre valores obrigatórios e valores preferenciais que foram mais tarde designados como valores intrínsecos ou finais e valores extrínsecos ou instrumentais (cf. Abbagnano, 1970, verbete 'valor'). 
No mundo moderno, a noção subjetiva de valor é retomada por Thomas Hobbes (1588-1679) que dizia que o valor não é absoluto, mas depende da necessidade de um juízo. Valor, portanto, é aquilo que é estimado como tal através de um juízo. A expressão "juízo de valor" (Werturteil), que parece ser de origem teológica, difundiu-se primeiro na Alemanha, de onde se propagou para todo o domínio filosófico. Neste campo há uma importante distinção a ser feita entre o ponto de vista do conhecimento ou explicação e o ponto de vista da avaliação. A confusão entre estes dois âmbitos reinou durante muito tempo e foi criticamente distinguida por Immanuel Kant (1724-1804) e David Hume (17111776) ao atribuírem à religião o ponto de vista avaliativo e à filosofia o ponto de vista intelectual, explicativo, do conhecimento 'noético'.

Para Kant o valor é o dever ser de uma norma (portanto, um a priori) que pode não ter realização prática, mas que atribui verdade, bondade e beleza às coisas julgáveis. Nesse sentido, os valores não têm realidade ou ser, mas são o dever ser (sollen). Esse ponto de partida kantiano foi explicitado por Heinrich Rickert (1863-1936) que menciona seis domínios de valor: a lógica, a estética, a mística, a ética, a erótica e a filosofia religiosa. A cada um desses domínios corresponde um bem: a ciência, a arte, o uno/todo, a comunidade livre, a comunidade do amor, o mundo divino. Por sua vez, a relação do sujeito com estes objetos se dá por meio de: juízo, intuição, adoração, ação autônoma, unificação, devoção. O sentido das coisas é a sua referência ao mundo dos valores que assim se inserem na história e são realizados pelos homens. Esta posição, seguida por muitos filósofos, reconhece, de um lado, que o valor está presente ao homem e suas atividades na forma de um dever ser e, por outro, supõe que seja independente e indiferente ao mundo humano. Nesse sentido, o valor é uno, universal e eterno, em contraposição à multiplicidade, particularidade e mutabilidade das manifestações concretas das quais deveriam ser a regra.

A solução de Kant do a priori transcendental não se mostrou eficiente. Procurando outro caminho, Max Scheler (1874-1928) chega ao intuicionismo, na experiência sui generis de natureza sentimental. Os valores são objetos completamente inacessíveis ao intelecto, que é cego como o ouvido para as cores. O valor é o objeto intencional do sentimento como a realidade é o objeto intencional do conhecimento. $\mathrm{O}$ modelo de Scheler ressuscita, ao nível do sentimento, a mesma antinomia entre o relativo e o absoluto dos modelos anteriores. Nicolai Hartmann 
(1882-1950) afirma que os valores só são tais com relação ao homem. São, portanto, relacionais (e não relativos), mas, por outro lado, afirma que os valores têm um ser em si, independente da opinião do sujeito, sendo, portanto, imutáveis e absolutos. ${ }^{2}$

O itinerário do termo 'valor' no mundo moderno deve-se em boa parte à obra de Nietzsche e ao escândalo que provocou sua intenção de inverter os valores tradicionais. Foi em Nietzsche, especialmente em suas obras Jenseits von Gut und Böse (1886) e Zur Genealogie der Moral (1887) que 'valor' tornou-se um dos conceitos centrais da filosofia em torno do qual girou, na sua quase totalidade, a discussão moral. É também desde essa época que se estabeleceu a distinção entre um conceito metafísico ou absoluto e um conceito empirista ou subjetivista de valor. Na primeira acepção, valor assume um status metafísico, independente de sua relação com o homem. No segundo sentido, valor inclui sua relação com o mundo humano, ou seja, com o homem e sua historicidade.

Em Jenseits von Gut und Böse encontra-se uma passagem na qual Nietzsche deposita sua esperança "em espíritos fortes e bastante independentes para dar impulsos a juízos de valor opostos, para reformar e inverter os valores eternos; em precursores ou homens do futuro que no presente formem o fundamento que abrigará a vontade dos milênios a abrir novos caminhos" (1886, $\$ 203$, p. 90$)$. Os valores tradicionais são ironizados por Nietzsche como valores eternos e invertê-los foi a principal finalidade de sua filosofia. Sua intenção era a substituição dos valores da moral cristã, a seu ver fundada sobre o ressentimento, ${ }^{3}$ portanto, sobre a renúncia e o ascetismo, por valores vitais que nascem da afirmação da vida e da aceitação dionisíaca.

Esta posição de Nietzsche foi interpretada como relativista e passou a ser o objeto preferido da crítica dos absolutistas. Na verdade, parece ser difícil comprovar um relativismo de valores a partir dos escritos de Nietzsche. O que ele queria era substituir os valores tradicionais calcados, como disse, no ressentimento por novos valores que favorecem a vida. Para Nietzsche, há uma relação intrínseca entre valor e ser humano, ou seja, não há valor independente do modo de ser do homem. Trata-se certamente de uma tese empiricista ou subjetivista, mas não relativista de valor.

O relativismo nasce de posições como a de Christian Ehrenfels (1859-1932) que define valor como a simples desejabilidade. Com isso, 
introduz-se pela primeira vez a noção de possibilidade. Valor não é a coisa desejada, mas o objeto desejável. O interesse efetivo é apenas uma possibilidade. Com este conceito nasce o relativismo dos valores no coração do historicismo, isto é, nasce o entendimento de que os valores têm relação com a história. Para Wilhelm Dilthey (1833-1911) é a própria história que institui e determina os valores, os ideais, a finalidade conforme se estabelecem os significados dos homens e dos acontecimentos. Os valores e as normas, portanto, nascem e morrem na história e não existem além nem acima do seu curso. A objetividade deriva apenas da correlação entre sujeito e objeto. Não existem valores absolutos; só existem aqueles que os homens reconhecem em determinadas circunstâncias. Os valores, portanto, não constituem uma realidade ontológica à parte, mas são uma qualificação categorial que pode referir-se a qualquer objeto.

Como se vê, atribuem-se ao valor dois caracteres contrastantes, o absoluto e o relativo: o primeiro constitui o modo de ser do valor em si e o segundo, o seu modo de ser na história. A história é aqui entendida como relativa, como uma criação humana. Esta também é a posição de Max Weber (1864-1920) que via na história uma incessante criação de valores, cada qual relativo ao fugaz momento em permanente luta com valores diferentes que se oferecem ao arbítrio do homem.

Este mesmo reconhecimento da pluralidade de valores encontra-se no filósofo norteamericano John Dewey (1859-1952), que definiu a filosofia como a crítica dos valores. Toda a valoração inteligente é também crítica porque faz um juízo a respeito da coisa que tem valor imediato. Toda a teoria do valor é necessariamente um ingresso ao campo da crítica. A crítica, nesse sentido, não é senão a disciplina inteligente das escolhas humanas. Tal teoria implica necessariamente uma avaliação da relação entre meios e fins. Não se pode escolher um fim sem pensar nos meios.

Todos estes conflitos nunca foram superados por qualquer posicionamento filosófico-ético que tivesse sido aceito não só como hegemônico, mas como consensual. Este rápido olhar histórico, feito sem pretensão teórica mais aprofundada, nos ajuda a ver que o conceito de valor é cheio de ambigüidades e varia de autor para autor e de época para época. Ainda hoje não encontramos nenhuma unanimidade a respeito de seu sentido. Como, então, falar de valores? Eu vou usar, no presente texto, o termo valor como princípios consensuados, dignos de servirem de orientação para as decisões e comportamentos éticos das pessoas que buscam uma vida digna, respeitosa e solidária numa sociedade justa e democrática. 


\section{Valores na vertente individualista}

A relação entre moral e educação ou, ao nível teórico, a relação entre ética e pedagogia vem sendo tematizada desde os primórdios de nossa cultura. Tais reflexões, que fazem parte das obras dos mais eminentes representantes da história do pensamento ocidental, culminam, não raro, na estilização de uma figura ideal de educador que, além de suas habilidades didáticas, também se distingue por sua postura moral exemplar. Para Platão, por exemplo, é a figura de Sócrates que incorpora o ideal de educador. ${ }^{4}$ Os ensinamentos e as posturas edificantes do educador Sócrates se destacam sobre o fundo de contraste constituído pela imagem negativa de outro tipo de educador que é a do sofista. No seu diálogo Protágoras, Platão descreve o sofista como aquele cuja força se encontra no discurso e que manipula os conhecimentos vendendo-os aos jovens a troco de pagamento. Protágoras, que era um dos mais destacados oradores dentre os sofistas, promete aos jovens um conhecimento mediante o qual se tornariam, dia a dia, mais virtuosos. Mas Platão acusa os sofistas de farsantes, uma vez que, ao invés da virtude, conforme prometem, estariam apenas ensinando a imoral arte de convencer e de manipular as pessoas.

Sócrates (Platão), ao contrário, defende a posição de que a virtude não pode ser ensinada. Em termos de educação moral, compara sua função à de uma parteira. Diz-se ignorante se dele se esperasse algum conhecimento ou receita no campo da moral. Não faz longos discursos sobre a moral como os sofistas, mas apenas perguntas perturbadoras que desestabilizam os jovens nas suas opiniōes e os induzem a buscar, eles mesmos, a solução de seus problemas. Com isso, os jovens percebiam que a virtude não decorre de um processo racional de explicações conceituais, senão que de uma reflexão pessoal e autônoma sobre as decisões práticas mais corretas. Competência moral só alcança aquele que aprende, por meio de esforço próprio, a agir com responsabilidade e não aquele que aprendeu fórmulas teóricas sem relevância prática. Para Sócrates, há uma relação intrínseca entre ética e educação, porquanto o conhecimento ético deve orientar o agir. Não sobre o educador e seus ensinamentos, mas sobre si mesmo é que o aluno deve fixar sua atenção para que aprenda a conduzir seu agir segundo a idéia de Bem. $\mathrm{O}$ educador não atua nem como exemplo nem como autoridade, mas como aquele que ajuda o educando a agir segundo a idéia de virtude (Bem) que se encontra em seu interior. 
Esta forma de pensar a moral a partir do indivíduo e da subjetividade perdurou pelos séculos afora, passando por Agostinho, Tomás de Aquino e pelos renascentistas, chegando até Jean Jacques Rousseau (1712-1778), que inaugura a perspectiva moderna logo assumida e vigorosamente desenvolvida por Kant. $\mathrm{O}$ pensador francês concentra sua atenção na figura do educando Emílio, cuja natureza é per se boa, e na educação negativa que deve preservá-lo das influências maléficas da sociedade. Ao educador do Emilio, que sugestivamente não tem nome, não cabe outra tarefa senão a de proteger seu protegido que, por si só, saberá desenvolver a sua natureza, aprendendo, aos poucos, os códigos morais que devem inspirar e orientar o seu comportamento. Coerentemente, Rousseau propõe o retorno ao estado natural e a uma educação que não interfira no desenvolvimento natural da criança. ${ }^{5}$

Para Kant, que, aliás, foi grande admirador de Rousseau, a educação tem a função de transformar o ser humano em ser humano: "O homem não pode tornar-se um verdadeiro homem senão pela educação. Ele é aquilo que a educação dele faz" (Kant, 1996, p. 15). Boa educação é aquela que dá origem a tudo o que há de bom no mundo. Para tanto, basta desenvolver os germes e disposiçôes para o bem que existem no interior do ser humano. Em contraposição ao bem, que é a ordem, o mal decorre da desregulamentação da natureza. Para Kant, o homem é um ser inacabado que tem em si uma disposição para o bem, que precisa ser desenvolvida. Já que o mal aparece quando permitimos que a natureza se desenvolva desregradamente, a educação moral consiste no cuidado de encaminhar as disposições naturais para o bem, mediante regras.

$\mathrm{O}$ processo educacional deve submeter a natureza humana a regras por meio da disciplinação, ${ }^{6}$ da cultivação, da civilização e da moralização. Esta função não pode ser cumprida pelo professor que transmite informações, mas pelo educador que educa para a vida. "O bom professor", assim Annemarie Pieper resume o pensamento de Kant, "deve estar, ele mesmo, comprometido com a idéia de liberdade, a qual é ao mesmo tempo o objetivo de sua atividade educativa na medida em que almeja transformar o educando num cidadão esclarecido, maduro, autônomo, capaz de autodeterminar-se e responder por seus atos" (2003, p. 143).

Sören Kierkegaard (1813-1855) retorna a Platão e reconhece em Sócrates o mais proeminente educador e filósofo moral. Kierkegaard parte do princípio de que qualquer 'comunicação ética' sempre tem um caráter indireto, uma vez que ela não é possível na forma de uma transmis- 
são direta de informação teórica. A educação ética só pode realizar-se como a indicação de uma 'capacidade' cuja realização só é possível a partir da liberdade de cada um. Com este objetivo, Kierkegaard escreve textos que propositadamente se aproximam dos diálogos platônicos, valendo-se do uso de pseudônimos com a intenção de desviar o leitor da pessoa do autor e, ao mesmo tempo, estimulá-lo a posicionar-se ante as posturas do autor. $\mathrm{O}$ educador deve dominar a arte dialética de levar uma vida em conformidade com as categorias morais e retrair-se enquanto pessoa na intenção de promover o desenvolvimento da autonomia moral do educando.

Na relação dos seres humanos entre si isto é o mais sublime: o educando é para o educador estímulo para que se conheça; o educador motiva o educando para o autoconhecimento; o educador não deixa após a morte nenhuma pretensão com relação à sua influência sobre a alma do educando, da mesma forma que o educando não pode imaginar que o educador lhe deva algo. (Pieper, 2003, p. 145)

Há muitos outros pensadores que poderiam ser citados como, por exemplo, Nietzsche, que cria a figura de Zaratustra na qual o engajamento moral e o interesse pedagógico formam uma unidade. Zaratustra ensina aos homens, por meio de imagens e alegorias, uma nova moral que ele mesmo vive: a moral do super-homem. "Eu vos anuncio o super-homem", diz Zaratustra às pessoas que encontrou no mercado. " $\mathrm{O}$ homem antigo é algo que deve ser superado. $\mathrm{O}$ que vocês fizeram para superá-lo? Todos os seres até agora criaram algo para além de si mesmos: e vocês pretendem ser a vazante dessa grande maré preferindo retornar ao animal ao invés de superar o homem?" (Nietzsche, s/d., p. 13). Segundo Nietzsche, o verdadeiro sentido do homem, o sentido da terra, encontra-se nele mesmo, encontra-se no caminho em direção ao super-homem. Este é um objetivo que não pode ser alcançado de uma vez por todas, mas apenas passo a passo, nos grandes momentos em que o homem encontra a sua identidade; nos momentos em que o sol se encontra a pino e as coisas não projetam sombras. O objetivo, no entanto, está no percurso do caminho, não na chegada; é o caminho que tem em si o destino.

Importante observar que todos estes autores, aos quais poderiam ser acrescentados tantos outros, viveram em épocas bastante distintas da nossa. Embora suas observaçôes e ensinamentos ainda sejam valiosos até hoje, encontramos também aspectos das relações entre ética e educação 
que ainda não existiam ao seu tempo. Aliás, Dilthey deixa este aspecto histórico da consciência ética em grande evidência. No seu livro Versuch einer Analyse des moralischen Bewusstseins (Tentativa de uma análise da consciência moral) Dilthey analisa a relação entre ética, pedagogia e filosofia da religião e conclui que a pedagogia recebe da ética os seus objetivos gerais e da psicologia os procedimentos e normas através dos quais ela pode alcançar tais objetivos. Como, porém, a ética não pode determinar, de uma vez por todas, o sentido da vida, uma vez que o ideal é sempre mutável e condicionado historicamente, a pedagogia pode ser uma teoria universalmente válida na medida em que assume aquelas normas éticas incondicionais que têm validade perene e não dependem das circunstâncias históricas.

Como podemos ver, a tradição ética, da qual aqui apenas pinçamos alguns momentos, está fundamentalmente focada no indivíduo. Sócrates, como não sabia responder à pergunta o que é o homem?, contenta-se com a busca e nos convida ao exame cuidadoso de nossas próprias vidas individuais, escutando sempre nossa consciência interior. Também Aristóteles, do qual nem falamos aqui, embora faça menção ao ethos social, referese à história como o domínio do indivíduo, do único e do irrepetível, colocando a responsabilidade do agir moral sobre o indivíduo. ${ }^{8}$ Também Santo Agostinho, que já preconiza o subjetivismo de Descartes, nos ensina que, para conhecermos o bem, temos que olhar para a nossa interioridade, onde à luz de Deus saberemos como melhor agir. Depois, já na modernidade, para além de Rousseau, Kant e Kierkegaard, também para Goethe o individuum est ineffabile.

\section{Valores na vertente social}

Há uma particular proximidade entre ética e pedagogia. Isto se deve ao fato de haver uma influência mútua entre moral e educação. $\mathrm{O}$ ser humano não é um ser moral por natureza, mas precisa ser educado para a moralidade. O comportamento natural do ser humano é, de início, egocêntrico (Piaget) no sentido de que, em princípio, são sempre as necessidades individuais que têm prevalência e orientam o agir das pessoas. À semelhança dos outros animais, portanto, o homem busca por natureza a vantagem própria, ou seja, a satisfação de suas necessidades, instintos e desejos. Se a este estado natural não fosse contraposta a exigência moral do reconhecimento, em grau de igualdade, das necessida- 
des dos outros seres humanos, instalar-se-ia aquela situação descrita por Hobbes no seu Leviatan: a guerra de todos contra todos, da qual sempre saem vencedores os mais fortes e hábeis. Posição, portanto, contrária à defendida por Rousseau que, no Emílio, assume, como vimos, o ponto de vista de que o homem é bom por natureza, pervertendo-se através do contato com a civilização e a cultura.

Tradicionalmente, tanto kantianos quanto utilitaristas começavam por estabelecer o bem, o dever, a utilidade como um axioma do qual deduziam, em seguida, algumas máximas que constituíam a moral prática e aplicada. Contra isso Durkheim afirma que moral não precede a realidade, mas deriva dela e a expressa. A seu ver, não se pode construir uma moral completa e impô-la mais tarde à realidade; ao contrário, é preciso observar a matéria para dela inferir a moral. É necessário entender a moral em suas múltiplas relações com os inúmeros fatos que lhe definem a forma e que ela, por sua vez, regula. Se for isolada deles, a moral parece não se relacionar a coisa alguma, mas flutuar no vazio (2003, p. 28). Durkheim (idem, p. 35) afirma que "a moral não é um sistema de regras abstratas que as pessoas trazem gravadas na consciência ou que são deduzidas pelo moralista no isolamento de sua sala. É uma função social ou, mais que isso, um sistema de funçôes formado e consolidado sob a pressão das necessidades coletivas".

Um dos conflitos fundamentais no campo da moral está ligado à natureza ambivalente do ser humano, que tanto é ser individual quanto social. A estas duas faces do humano ligam-se duas estratégias da formação moral das quais uma privilegia o aspecto subjetivo/individual e a outra o aspecto intersubjetivo/social. Aqueles autores que assumem leituras sociológicas e que têm em Durkheim seu mestre maior defendem a posição de que a educação moral deve integrar os indivíduos na comunidade. Para o sociólogo francês,

a moral e o direito são apenas hábitos coletivos, padrões constantes de ação que se tornam comuns a toda uma sociedade (...) e à medida que o meio em que vivemos se torna a cada dia mais complexo e mais flexível, devemos ter a iniciativa e a espontaneidade necessárias para segui-lo em todas as suas variaçōes, para mudar conforme ele muda. (Durkheim 2003, p. 24)

Durkheim usa a beleza plástica da alegoria para expressar seu entendimento da relação entre moral e sociedade: "a vida econômica desenvolve um leito ao qual se ajusta o material que por ele flui" (idem, ibid.). 
É incisiva a sua crítica aos modelos metafísicos ou teológicos de moral: "Não se pode construir uma moral completa e impô-la mais tarde à realidade; ao contrário, é preciso observar a realidade para dela inferir a moral. É necessário entender a moral em suas múltiplas relações com os inúmeros fatos que lhe definem a forma e que ela, por sua vez, regula”. Como vemos, a formação moral aparece no texto de Durkheim como um processo mediante o qual os indivíduos recebem da sociedade os valores e normas vigentes. Tais preceitos são impostos aos indivíduos a partir de uma autoridade superior externa à qual não podem opor-se, restandolhe como única alternativa a submissão. As normas morais são obra coletiva sobre a qual os indivíduos têm pouca ou nenhuma influência. "Assim a maior parte das instituiçóes morais ou sociais não são resultantes de cálculo ou razão, mas de causas obscuras, de sentimentos subconscientes e de motivos que não têm qualquer relação com os efeitos que produzem e que, em conseqüência, eles não podem explicar" (idem, ibid., p. 33-34).

Trata-se de uma concepção de moral caracterizada pela imposição, sem espaço para a autonomia e a responsabilidade do sujeito. Este não tem outra tarefa senão esforçar-se para conhecer a natureza e a razão das normas sociais e incorporá-las. E é mediante este processo de reconhecimento e incorporação que se abre ao sujeito a possibilidade de superar sua determinação e heteronomia e conquistar a autonomia. Assimilando as normas, tornando-as de certo modo suas, o indivíduo reconquista sua autonomia.

Dessa concepção de moral decorre um modelo de educação que consiste na transmissão de valores fixos e inapeláveis de geração em geração. As crianças e jovens são levados a reconhecer a autoridade e seguir seus mandamentos. Durante muito tempo, este tipo de educação ficou a cargo da religião. Com o descrédito da autoridade religiosa e a crescente racionalização da sociedade ocidental, a solução heterônoma sofreu uma profunda revisão, passando a assumir traços de uma ética laica.

Mesmo assim, e apesar do distanciamento da esfera religiosa, as novas éticas, embora não religiosas, preservaram, sobre outra base, o mesmo princípio da autoridade. Entre elas incluem-se aquelas de vertente historicista e sociológica. As primeiras partem do princípio de que a história é determinada por leis inexoráveis que antecipam o futuro. Assim sendo, basta assumir como princípios orientadores do comportamento moral aqueles valores que presumivelmente serão predominantes no fu- 
turo. As de vertente sociológica, por sua vez, assumem os fatos morais como determinados exclusivamente pelas condições sociais.

No seu intento de fugir dos valores impostos pela religião, Durkheim cai, por sua vez, em nova autoridade externa e heteronômica: a sociedade. (...) É a sociedade que, uma vez abandonadas as crenças religiosas, se constitui no elemento a que devem ser submetidas a vontade e a conduta das pessoas". (Puig, 1998, p. 31)

Também neste caso, o sujeito não é livre para tomar suas próprias decisões de acordo com a sua consciência. A consciência deve submeterse às normas e valores vigentes na sociedade. Agir moralmente significa agir em conformidade com as normas estabelecidas em sociedade. A nova autoridade moral que substitui a autoridade religiosa como poder legitimador das normas, tornando-as obrigatórias para todos, é a própria sociedade. Para Durkheim, agir moralmente é agir segundo o interesse coletivo e, neste sentido, moral pressupõe disciplina e, numa fase mais avançada, adesão, solidariedade e vinculação ao grupo social. Os seres humanos reconhecem na sociedade algo superior à sua individualidade e acreditam que agindo segundo o interesse coletivo realizam de forma melhor sua própria natureza, "pois moral e direito são apenas hábitos coletivos, padrōes constantes de ação que se tornam comuns a toda uma sociedade. Em outras palavras, são como a cristalização do comportamento humano" (Durkheim, 2003, p. 24).

Como, porém, conciliar esta moral que é imposta a partir de fora com a autonomia da vontade individual? Durkheim responde aludindo às ciências naturais: tornamo-nos livres perante a natureza respeitando as suas leis. Analogamente nos tornamos livres na sociedade reconhecendo as razões porque suas normas e leis nos são impostas. Para o sociólogo francês, "é necessário proceder da mesma forma em moral. O bem, os deveres e os direitos não são dados da experiência. O que observamos diretamente são bens, deveres e direitos particulares. Para descobrir a fórmula que abrange todos é necessário estudar primeiro cada um em si, em vez de tentar absorver num só fôlego uma definição geral da moralidade" (idem, ibid., p. 116).

Facilmente podemos reconhecer que, segundo esta proposta de Durkheim que se reduz à aceitação e reconhecimento das normas e valores morais vigentes na sociedade, a educação moral fica reduzida à socialização. De fato, na escola os alunos devem ser educados para a discipli- 
na (obedecer e observar as normas) e para o reconhecimento das normas (aceitá-las porque representam a melhor forma de convivência). Neste modelo, o educador evidentemente assume uma função central como autoridade moral que deve exigir disciplina, ainda que de forma dosada, de modo que as exigências não sejam como um fardo, mas reconhecidas como necessidade social. Pela educação moral, o indivíduo é levado a aderir à sociedade política em geral.

Não se pode negar que o modelo de Durkheim fomenta no aluno o gosto pela vida comunitária desde o momento em que ele entra na escola. É tarefa da escola e do professor, enquanto autoridade moral, criar nos jovens o sentimento de vinculação e de pertença a uma coletividade. Mas, de outra parte, a educação moral fica reduzida à adaptação heterônoma ao modelo social vigente, esquecendo a questão da formação da consciência moral autônoma. A autonomia moral em Durkheim não inclui o questionamento e eventual recusa da norma. Não há, portanto, a possibilidade da dissidência ou do inconformismo.

\section{O crepúsculo do dever ${ }^{9}$}

Além dessas proposições positivas, há aqueles autores que dizem que qualquer tentativa de fundamentar a moral está fadada ao insucesso. Preferem dizer que a moral não pode ser fundamentada. Hoje são, sobretudo, os pós-modernos que assumem tal posição. Tudo começou com Nietzsche e depois Heidegger, que lançam uma virulenta crítica contra a metafísica e a razão moderna, a razão que se atribui a capacidade de tudo poder fundamentar. Com isso, lançam as raízes do movimento de ceticismo moral que hoje designamos como pós-modernidade. "A modernidade", diz Vattimo (1992, p. 20), "é a época da legitimação metafísico-historicista, a pós-modernidade é o questionamento explícito deste modo de legitimação". Neste contexto, conforme observa Bauman (1997, p. 6), “a própria ética é denegrida e escarnecida como uma das construçóes tipicamente modernas agora quebradas e destinadas ao cesto de lixo da história; grilhóes uma vez considerados necessários, agora estimados claramente supérfluos: outra ilusão que homens e mulheres pós-modernos podem muito bem dispensar”. Os representantes dessa nova orientação foram duros em suas críticas sentenciando que a modernidade levou "ao máximo de depuração o ideal ético" pelo enaltecimento das virtudes laicas, das obrigaçóes 
e dos sacrifícios, não chegando a romper, efetivamente, com a moral da renúncia ditada pelo "esquema religioso da imperatividade ilimitada dos deveres” (Lipovetsky, 1992, p. 16). O primeiro ciclo da moral moderna teria funcionado como uma religião do dever laico, e este período estaria agora esgotado dando início a uma nova era, a era do pós-dever. "Pela primeira vez, eis uma sociedade que, longe de exaltar os mandamentos superiores, os eufemiza e os desacredita, desvaloriza o ideal de abnegação estimulando sistematicamente os desejos imediatos, a paixão do ego, a felicidade intimista e materialista" (idem, ibid.). Esta nova era a que teríamos chegado é a da sociedade pós-moralista ou também denominada 'era do vazio' ${ }^{10}$ : "uma sociedade que repudia a retórica do dever austero, integral, maniqueísta, e que, paralelamente, exalta os direitos individuais à autonomia, ao desejo e à felicidade" (idem, ibid., p. 17).

Não se trata, porém, de imaginar que a ética do pós-dever faça desaparecer as correntes que lhe são contrárias, nem significa que o pósdever seja sinônimo da entrada numa era da tolerância permissiva. Os grandes debates em torno de temas fundamentais como o aborto, a eutanásia, a manipulação genética, as agressões ao meio ambiente, entre outros, continuam carentes de regulamentação e talvez cada vez mais severos. Seria caricatural imaginar uma época à margem do dever em que toda e qualquer vontade moral se desintegraria, mas é forçoso admitir que, em muitos setores da vida social, para o bem ou para o mal, assumem importância novas formas de individualismo que buscam livrar-se dos controles e regras. O rosto do futuro será marcado, na leitura de Lipovetsky (op. cit., p. 19), pela

imagem desta luta a que se entregam estas duas lógicas antagônicas; uma, afastando-se da obsessão da finalidade, tendo em conta a complexidade tanto do social como das situações individuais, inventando dispositivos plurais, experimentais, personalizados; a outra, desviando-se das realidades sociais e individuais em nome de um novo dogmatismo ético e jurídico.

No entanto, se bem é verdade que os defensores das posições pósmodernas, como é o caso do autor que estou citando, ${ }^{11}$ colocam o individualismo no centro da lógica que rege a contemporaneidade, é preciso reconhecer, em contrapartida, que se fala de dois tipos de individualismo: "De um lado, o individualismo ligado às regras morais, à equidade, ao futuro; do outro, o individualismo do cada um por si e do 'depois de 
mim, o dilúvio'; ou seja, em termos éticos, o individualismo responsável e o individualismo irresponsável". (Lipovetsky, op. cit., p. 20). E é preciso acrescentar ainda que pelo menos Lipovetsky se posiciona claramente a favor do primeiro tipo de individualismo, embora alerte que não haverá desfecho final no embate entre estas duas lógicas do individualismo. Elas vão continuar a entrechocar-se em decorrência da cultura que reduz os deveres e enaltece os direitos e interesses subjetivos. "O sentido da responsabilidade reconstitui-se em novas bases conformes à realização do ego" (idem, ibid., p. 217).

Esta explicação, no entanto, não livra estes autores da grave crítica de que eles, no fundo, ficam presos ao individual deixando de lado esta que talvez seja, ou pelo menos deveria ser, a mais fundamental preocupação ética dos dias atuais: a preocupação com o social. Do ponto de vista político, poderíamos dizer que os pós-modernos operam no contexto capitalista neoliberal, adaptando a ética à sua lógica e principais teses e abandonando a perspectiva socialista como utopia para o futuro da sociedade. Esta não é uma conclusão viesada por quem tem uma leitura diferente, mas se trata de uma posição textualmente assumida:

É em torno deste conflito 'estrutural' do individualismo que se joga o futuro das democracias: fazer recuar o individualismo irresponsável, redefinir as condições políticas, sociais, empresariais, escolares, capazes de fazer progredir o individualismo responsável - não existe tarefa mais crucial (...). Aí reside uma das razôes do sucesso da ética: ela entra em estado de graça no momento em que os grandes breviários ideológicos deixam de responder às urgências desse momento. (Lipovetsky, op. cit., p. 21)

Seria de certo modo desnecessário dizer, mesmo porque é do conhecimento geral, que as teses defendidas pelos pós-modernos são extremamente polêmicas. Bauman (1997, p. 8), por exemplo, pergunta: "Resta a ver se o tempo de pós-modernidade passará para a história como crepúsculo ou como renascimento da moralidade". A meu ver, como já expus em outro trabalho (Goergen, 2005), os pós-modernos nos ensinam muito em termos do reconhecimento das características subjacentes ao curso da história contemporânea. De fato, não há como negar que estamos distantes de um período em que havia um código ético fixo, universal e perene, que era, bem ou mal, aceito por todos e pelo qual todos tinham que regular seu comportamento. Há, sem dúvida, uma desconstrução (Derrida) de tal estrutura ética rígida e fixa. De outra parte, pare- 
ce que os pós-modernos se acomodam a esta situação e perdem a perspectiva histórica da construção de uma sociedade melhor, mais digna e justa. Perdem o sentido da utopia, daquilo que ainda não é lugar e que, talvez, nunca venha a sê-lo na forma sonhada, mas que deve servir de impulso e orientação para o caminhar.

Do ponto de vista da educação, vejo a posição pós-moderna com preocupação, sobretudo no contexto de nossa realidade social que precisa procurar alternativas para a situação de desigualdade, de carências múltiplas em que se encontra, que, portanto, precisa de utopias. Estes argumentos encontram respaldo até mesmo em autores pós-modernos como, por exemplo, Gianni Vattimo, que nos diz, de um lado, que "a modernidade é a época da legitimação metafísico-historicista, a pós-modernidade representa o questionamento explícito deste modo de legitimação" e acrescenta, de outro, que "as dificuldades do pensamento pós-moderno mostram que não se pode deixar vacante sem mais o posto antes ocupado pelos 'metarrelatos' e pela filosofia da história" (1992, p. 20 e 35). E com isso podemos concluir com Bauman (1997, p. 8) que "os grandes temas da ética - como direitos humanos, justiça social, equilíbrio entre cooperação pacífica e auto-afirmação pessoal, sincronização da conduta individual e do bem-estar coletivo - não perderam em nada a sua atualidade. Apenas precisam ser vistos e tratados de maneira nova”.

\section{O dever como decorrência do agir comunicativo}

$\mathrm{Na}$ verdade, o processo que derrubou o velho estilo de vida na passagem para a era moderna não foi apenas rápido senão também traumático. O século XIX está repleto de teorias críticas com relação aos resultados devastadores da vida moderna. Estas teorias assinalam, sobretudo, o caráter mecânico da nova forma de vida em contraposição à organicidade da velha ordem, a perda da tradição, da segurança e a perda tanto do lar metafísico quanto do empírico (Heller, 1999, p. 18). Estas críticas, expressas com vigor por Nietzsche, foram renovadas no século XX por Heidegger e Adorno. Vejamos como Heller (op. cit., p. 18-19) resume o novo cenário:

o ritmo acelerado de decomposição da estrutura familiar e o alerta sobre o desequilíbrio ecológico crescente no interior do Primeiro Mundo são ansiedades semelhantes àquelas do século passado. A ameaça parece ainda mais 
grave por causa da transformação das experiências da vida quotidiana, com a introdução, nos lares e mesmo na vida íntima, de uma tecnologia sempre em mudança. Tem-se que mudar hábitos, idéias e credos - e reaprender praticamente tudo três vezes na vida. Quanto tempo se consegue resistir? Quantas vezes podem as pessoas mudar de atitude na vida? Quantas vezes podem as pessoas mudar de profissão? Quantas vezes podem assumir novas orientações? Homens e mulheres sentem que estão perdendo terreno.

Não são apenas os conteúdos que o educando vai assumindo ao longo do processo de aprendizagem que têm influência sobre sua formação moral, mas também o comportamento dos educadores, sejam pais ou professores, se encontra ao abrigo das categorias da moralidade. Estes dois aspectos - o conteúdo assimilado pelos educandos e as atitudes dos educadores - revelam tanto a mediatividade ética da pedagogia quanto a mediação moral da educação.

Este aspecto histórico também é salientado pelos representantes da chamada Escola de Frankfurt, cujos representantes mais destacados como Horkheimer, Adorno e Marcuse e, numa fase mais recente, Habermas defendem a idéia de educação moral focada na melhoria das condições sociais e que, por conseguinte, tem as características de uma educação política. A teoria crítica investe num conceito de consciência moral que se realiza na conscientização dos jovens e adultos a respeito da necessidade de transformaçôes sociais e individuais que visem uma organização social mais digna e justa. Educação é compreendida como um modo de práxis social que, mediante a comunicação, promova a assunção de convicções e práticas comprometidas com a superação da desumanidade e barbárie que marcam a sociedade contemporânea. O educador deve ele próprio assumir compromissos políticos, colocando seu engajamento ao debate público para motivar os educandos a se engajarem também na luta pela melhoria das condições sociais.

Habermas, cuja filiação à Escola de Frankfurt é bastante controversa $^{12}$ por causa de seu posicionamento crítico com relação a algumas de suas teses, desenvolve um projeto teórico que pretende lançar os fundamentos de uma nova compreensão da razão, do ser humano e da sociedade. $\mathrm{O}$ foco principal de sua proposta consiste na substituição do paradigma da consciência pelo da intersubjetividade. A racionalidade não se atrela à subjetividade como imaginou Descartes e toda a filosofia moderna, mas à relação intersubjetiva da qual emerge, por conseguinte, a toda a cultura. 
A chamada 'ética da discussão', elaborada por Jürgen Habermas e Karl Otto Apel enquadra-se nesta perspectiva da descentralização com relação ao sujeito. Ambos os autores se colocam na perspectiva da tradição ética kantiana com a pretensão de superar as suas deficiências. Habermas e Apel concordam com Kant que o mundo da moral é o mundo da autonomia do ser humano, portanto, das leis que o homem cria para si mesmo, mas discordam de Kant no tocante à interpretação do que significa criar suas próprias leis.

Enquanto Kant entende que cada um de nós decide quais são as leis que considera próprias das pessoas, Habermas e Apel afirmam que quem deve decidir isso são as pessoas afetadas por elas. Esta decisão deve ser tomada com base num entendimento alcançado mediante um diálogo entre os agentes em condições iguais de racionalidade. A exemplo do que fazem ao nível da razão teorética, Habermas e Apel entendem que a razão moral não é uma razão monológica, mas uma razão dialógico-comunicativa. É pelo diálogo e não individualmente que devemos chegar à conclusão se uma norma moral é correta ou não. Trata-se de um diálogo entre todos aqueles que são afetados pelas normas e que os leva ao convencimento de que as normas em discussão são as melhores para todos. "As argumentações servem para tematizar e examinar as pretensôes de validez que as pessoas erguem a princípio implicitamente e levam consigo ingenuamente no agir comunicativo" (Habermas, 1989, p. 193). É este consenso que confere autoridade à norma de modo que ela possa ser considerada obrigatória para todos. "O conceito da legitimidade das normas de ação", diz Habermas (op. cit., p. 196), "é decomposto nos componentes do reconhecimento factual e da qualidade de ser digno de reconhecimento". Trata-se, portanto, de uma nova forma de legitimação de normas e valores que passa não pela autoridade externa, nem simplesmente pela autoridade das práticas objetiva e positivamente existentes, mas pelo agir comunicativo das pessoas que, mediante o discurso, buscam consensos a respeito daquilo que, do ponto de vista do comportamento moral, é melhor para cada um e para todos.

Num tempo em que todos se questionam a respeito dos fundamentos das normas e dos valores, Apel e Habermas ${ }^{13}$ procuram ancorar a ética nos pressupostos pragmáticos da linguagem, sugerindo, por esta via, uma fundamentação intersubjetiva e racional das normas. Habermas combate o modelo subjetivista e monológico da razão e da ética, substituindo-o por um modelo verdadeiramente dialógico que somente a ética 
do discurso ou, talvez melhor, a ética da discussão tem condições de sustentar. "É só na qualidade de participantes de um diálogo abrangente e voltado para o consenso, que somos chamados a exercer a virtude cognitiva da empatia em relação às nossas diferenças recíprocas na percepção de uma mesma situação" (Habermas, 2004, p. 10). Mesmo sem negar a subjetividade, Habermas insiste que "a vontade de uma pessoa é determinada por motivos que deveriam igualmente ser levados em conta por todas as outras pessoas" (idem, ibid., p. 12).

A própria autonomia não pode ser alcançada individualmente. Ela só pode explicitar-se dentro de uma estrutura intersubjetiva. A partir desses pressupostos intersubjetivos da própria subjetividade, Habermas (op. cit., p. 13) pode "conceber a comunidade moral como uma comunidade abrangente que faz suas próprias leis, uma comunidade formada de indivíduos livres e iguais que se sentem obrigados a tratar uns aos outros como fins em si mesmos".

O fundamento da norma, portanto, não assenta sobre o princípio da autoridade externa à comunidade, senão que

o que pesa sobre as decisões dos participantes de um discurso prático é a força de obrigatoriedade daquela espécie de razóes que, em tese, podem convencer a todos igualmente - não só as razões que refletem as minhas preferências, ou as de qualquer outra pessoa, mas as razôes à luz das quais todos os participantes podem descobrir juntos, dado um assunto que precisa ser regulamentado, qual a prática que pode atender igualmente aos interesses de todos. $(2004: 14 / 15)$

Esta posição de Habermas tem duas implicações importantes. Primeiro que a proposta da ética da discussão pressupõe a existência de participantes (da discussão) que sejam dotados de autoridade epistêmica, ou seja, tenham condições de emitir juízos argumentados; e segundo, que tais sujeitos estejam dispostos a procurar acordos racionais aceitáveis para todos os envolvidos e todos os que forem afetados por eles. Tal pressuposto teórico representa, em termos práticos, a tarefa política de se buscar uma sociedade na qual haja as melhores condiçóes possíveis de participação de todos no agir comunicativo, fundamento da moral e da própria organização social.

Apesar das consideráveis diferenças entre as posições dos vários autores com relação a esta temática que estamos estudando, parece-me possível destacar pelo menos duas concordâncias básicas. Primeiro, parece 
haver consenso de que objetivos éticos são indispensáveis para qualquer teoria da educação. Isto porque, em última instância, é a idéia de ideal humano, isto é, a imagem do que e do como o homem deve ser, que decide sobre os conteúdos da educação e suas formas de transmissão. Estas representações normativas a respeito do ideal de ser humano, que se tornam paradigmáticas para os conteúdos e o agir educativo, vêm mescladas às condiçōes empíricas e concretas do espírito de cada época. É tarefa da ética recordar permanentemente que tais representações historicamente condicionadas não se tornem fixas ou dogmáticas, evitando, com isso, que, dogmaticamente paralisadas, se distanciem da própria realidade. A reflexão ética deve manter acesa a chama da realização dialética entre o ideal e o real, uma vez que é nessa tensão que acontece a prática humana.

Em segundo lugar, parece bastante claro que este objetivo de uma educação para a consciência e responsabilidade co-determina também as atitudes e funções do educador. $\mathrm{O}$ educador deve subsidiar, mediante as relevâncias que imprime aos conteúdos que ministra e suas atitudes didáticas, o processo de desenvolvimento da liberdade, da emancipação e da responsabilização dos educandos. Neste processo, suas aulas não podem resultar em doutrinação, senão que num processo discursivoargumentativo que vise sempre motivar o educando para que assuma gradativamente sua autonomia pessoal e responsabilidade social.

A ética do discurso procura, pelo menos na versão apresentada por Habermas, superar os limites dos fundamentos transcendentais ${ }^{14}$ da ética tradicional e ao mesmo tempo contestar "a suposição básica do relativismo ético, segundo o qual a validez dos juízos morais só se mede pelos padrões de racionalidade ou de valor da cultura ou forma de vida à qual pertença em cada caso o sujeito que julga" (Habermas, 1989, p. 147) sem abrir mão da pretensão de universalidade. Embora a Ética do Discurso não dê "nenhuma orientação conteudística, mas sim, um procedimento rico de pressupostos, que deve garantir a imparcialidade da formação de juízos" (idem, ibid., p. 148), ela representa uma nova forma de fundamentação dos valores sobre uma nova base intersubjetiva que envolve todos os concernidos.

\section{Educação e a formação do sujeito moral}

Quando os valores absolutos entram em crise geralmente se impõe uma concepção relativista de valores, que transferem as instâncias 
decisivas para o âmbito da subjetividade. Este encaminhamento não reconhece mais que haja a possibilidade de soluçôes universais e generalizáveis para os problemas morais. $\mathrm{O}$ fato de se negar a possibilidade de soluções generalizáveis não significa a imposição da indiferença ou do relativismo diante das controvérsias morais. Significa apenas que as controvérsias têm que ser resolvidas mediante decisōes individuais pelos indivíduos afetados. Do ponto de vista educacional, isto significa que o professor deve levar os seus alunos a refletir sobre quais são os valores com os quais podem sentir-se comprometidos e responsáveis. A tarefa educativa fica reduzida ao estímulo da reflexão pessoal e do esclarecimento pessoal dos alunos. Cada indivíduo é responsável pela construção de sua própria vida e, no que se refere aos valores de ordem pública e social, serão as contribuições científicas e técnicas que irão decidir. Neste caso,

atuar como uma pessoa moralmente adulta implica assumir a sua responsabilidade sem esperar dos demais respostas nem soluçōes para os próprios conflitos de valores. De alguma maneira considera-se que o isolamento ou a solidão é, no fundo, o destino do ser humano e que não se deve esperar das relações sociais e da convivência algo que não podem proporcionar. (Puig, 1998, p. 40-41)

Tal atitude, naturalmente, supõe a tolerância com relação aos posicionamentos subjetivos divergentes, o que, em caso extremo, significa a indiferença ou equivalência entre valores e, no limite, um certo relativismo moral. Uma das características desta compreensão moral é a concepção de valor como processo. $\mathrm{O}$ valor não é algo estático que possa ser conhecido e depois conservado. Ele depende das experiências e do processo de amadurecimento dos sujeitos. No processo educativo, isso significa que o adulto deverá renunciar a qualquer tentativa de persuadir os jovens a aceitar um conjunto predeterminado de valores. A única coisa que a educação pode fazer é estimular o aluno a assumir o próprio processo de valoração. ${ }^{15}$

A formação moral é um processo complexo que abriga diversos aspectos, desde a incorporação das convenções sociais até a formação da consciência moral autônoma. As formas de aquisição de tais requisitos incluem a reflexão e as atitudes pessoais até os sentimentos e comportamentos que são estimulados pela educação formal ou informal, como também pela simbiose ou mímese cultural. A educação moral, entendida como o conjunto de todos estes movimentos, é um processo de construção sócio-cultural da personalidade ou do sujeito moral. 
A educação moral pode ser entendida como um dos aspectos da educação integral, que abrange a educação corporal, a educação intelectual, a educação afetiva, a educação artística, para ficarmos apenas nos aspectos mais tradicionais. A educação ocupa um lugar de destaque porque pretende dar uma orientação e um sentido ao ser humano como um todo; ela, de certo modo, perpassa transversalmente todas as dimensões da formação humana.

Desde um ponto de vista geral, podemos dizer que a educação busca formar um ser humano capaz de lidar com o meio e com os outros seres humanos. De certo modo, a educação é uma adaptação ao meio, mas "não busca uma adaptação fixa, e sim uma adaptação sempre inacabada: uma adaptação otimizante, crítica e evolutiva" (Puig, 1998, p. 24). Hoje, privilegiamos um conceito de educação voltado para o aspecto intelectual, em especial para a aquisição de conhecimentos e informações para a interpretação do mundo e o preparo profissional. É a aquisição das disposições necessárias para a adaptação do ser humano ao meio no qual as pessoas devem viver. Se tradicionalmente esta adaptação tinha um caráter fixo, hoje, por conta da realidade em permanente mudança, é uma adaptação sempre inacabada. Este processo envolve o sujeito numa relação de troca constante com o curso da realidade que o expõe ao risco de uma submissão constante às urgências dessa realidade. De certo modo, o sujeito individual não tem como se evadir desta necessidade de adaptação, a não ser que escolha ser um outsider. Resta-lhe, no entanto, a possibilidade de uma adaptação crítica e da preservação de sua autonomia mediante a atividade reflexiva e "a busca cooperativa da verdade de uma comunidade comunicacional”, como um mecanismo de transformação da realidade. Estas observações podem parecer um tanto desalentadoras diante de uma realidade tão desumana e carente de transformações, mas não nos resta, pelo menos para o momento, outra alternativa senão preservar certo compromisso com o realismo. Isto não faz senão aumentar a responsabilidade para com uma educação cidadã comprometida com os ideais da democracia. ${ }^{16}$

Esta adaptação crítica que acontece em diferentes níveis (o natural e o artificial, o social e o institucional e o pessoal ou íntimo) é definida por Puig como uma adaptação otimizante, aberta, criativa e evolutiva, como "um processo no qual não estão decididos de antemão nem a direção nem a forma como a adaptação se dará; não estão decididas as finalidades que os mecanismos adaptativos irão perseguir nem o modo como 
serão alcançadas tais finalidades" (Puig, 1998, p. 25). Precisamos, portanto, decidir como queremos que sejam essas relações com os outros, com o meio e conosco mesmos. "A adaptação crítica pressupõe, pois, conhecer tal possibilidade de decisão e usá-la de modo consciente, livre e responsável" (idem, ibid., p. 25). Essa perspectiva representa uma forma de utopia real que tanto permaneça sempre ideal quanto também se realiza no presente mediante nosso empenho e esforço.

Apesar deste prospectivismo de Puig, sua posição parece-me muito acomodada, pelo menos no caso de um contexto social como o brasileiro. Diante das gritantes injustiças sociais e da situação desumana em que vive a grande maioria da população, falar de adaptação 'otimizante' lembra o tradicional individualismo subjetivista que parece superado na perspectiva de Habermas.

O ser humano só é ou só pode ser um sujeito moral na medida em que é indeterminado e livre. Se fôssemos programados como os animais, não poderíamos falar de moralidade. De outra parte, a liberdade implica a capacidade de refletir sobre o processo de aprendizagem e a capacidade de dar a este processo a orientação que desejamos. Quando no encontramos diante da decisão de como desejamos viver, que atitudes tomar ante os conflitos vitais, como nos relacionar com o meio e com os outros, estamos diante da condição humana que denominamos moralidade. É o jogo entre a determinação e a possibilidade de decidir a respeito da orientação que queremos dar à nossa vida. Disso já é possível extrair uma primeira elucidação do que é educação moral: a busca de um caminho pessoal para uma vida consciente, livre e responsável. Do ponto de vista do educador, pode-se dizer que sua influência educativa deve contribuir para um sujeito consciente e autônomo, capaz de decidir que atitudes tomar que, na busca da felicidade, preservem tanto interesses individuais quanto sociais.

A essa primeira junta-se uma segunda e importante dimensão, geralmente secundarizada pelas éticas individualistas ou subjetivistas. Se concordarmos que o protagonista do processo de atitudes e decisões é, antes de tudo, o sujeito individual e autônomo, é preciso acrescentar imediatamente que esse sujeito não existe, não pensa, nem age sozinho. $\mathrm{O}$ ser humano por sua própria condição humana vive e age em situação social. Ademais, sua linguagem, sua forma de pensar, de sentir e de julgar são fruto da história de suas relações com a natureza e com os outros homens. É no contexto da convivência que se abrem para ele todas as possibilidades, mas também se impóem os limites e as normas. 
A moralidade caracteriza-se por esta tensão ou polaridade entre o individual e o social. Do ponto de vista individual, a pessoa busca a satisfação de seus desejos, impulsos e instintos; do ponto de vista social, tais impulsos individuais conflitam com os de outras individualidades e precisam encontrar formas de equilíbrio que permitam a convivência respeitosa e pacífica. No interesse de todos é preciso encontrar formas de entendimento (consensos) sobre como se portar para garantir condiçôes de vida e liberdade para todos. Caso contrário, valeria apenas a lei do mais forte, instalar-se-ia a guerra de todos contra todos. Neste sentido, compete à educação moral, é verdade, "a tarefa de ensinar a cada um dos sujeitos e aos diferentes grupos humanos a viver no seio de uma comunidade" (Puig, 1998, p. 27), mas também o empenho de transformar esta sociedade numa sociedade mais digna e justa para todos.

Além dos aspectos apontados nas duas observações anteriores relativas à dimensão individual e social da moral, há um terceiro elemento que desde os tempos mais remotos de nossa cultura ocupa os teóricos que trataram das questôes morais. Trata-se do objetivo modelador do comportamento moral, ou seja, da idéia de bem ou de valor. O comportamento moral não se esgota na decisão de como viver individualmente e no contexto de uma comunidade, mas de decidir qual a melhor forma de fazê-lo, isto é, quais os valores que devem orientar os comportamentos das pessoas na sua vida particular e social. Sabemos que não existem consensos naturais a respeito dos valores que deveriam orientar o comportamento individual e social das pessoas. Para as situações concretas que exigem decisões morais abre-se sempre a possibilidade de vários caminhos dentre os quais é preciso escolher, tendo em vista o pessoalmente desejável e o socialmente justo. Em muitos casos, surgem conflitos em função de interesses, pontos de vista, convicções políticas, religiosas, ideológicas etc. Pode-se dizer que esta conflitualidade é inerente à própria natureza da moral. Estes conflitos precisam ser trabalhados de modo a se alcançar propostas adequadas para os indivíduos e para a coletividade. Tais propostas se cristalizam na forma de conteúdos morais na cultura que são transmitidos de geração em geração, mas que também estão sujeitos a serem criticados e revistos, na medida em que se revelarem inadequados aos desejos individuais e aos interesses coletivos que se transformam ao ritmo das mudanças materiais que conduzem a trajetória histórica.

Recebido e aprovado em setembro de 2005. 


\section{Notas}

1. Escola filosófica grega, cerca de 300 a.C., fundada por Zenon, segundo a qual o ser humano é uma parte do Deus/natureza. A força motora de tudo é Deus, que tudo ilumina, sendo a matéria uma modificação desta força divina. O homem é livre no interior da razão universal. Ele deve cultivar sua força interior independente. A moral estóica se preserva até hoje no ideal do gentleman.

2. Estes autores estão sendo citados livremente com base em Abbagnano (cf. bibliografia).

3. Max Schleler dedicou um de seus livros Das Ressentiment im Aufbau der Moralen (O ressentimento na construção das morais) ao ressentimento como fundamento da moral.

4. Para esta função que Sócrates exerce na obra platônica, pouco importa se Sócrates existia de fato ou não.

5. Esta é a razão porque o Emílio deve ser lido à luz do Contrato social. São duas obras que se complementam. A tese de que o homem é bom por natureza e que se deteriora no contato com a civilização também nos permite entender o conceito de educação negativa, que não é outra coisa senão uma educação que busca proteger o indivíduo das influências maléficas da civilização e da cultura.

6. "A disciplina é o que impede ao homem de desviar-se do seu destino, de desviar-se da humanidade, através das suas inclinaçôes animais" (Kant, 1996, p. 12).

7. Merece atenção o fato de que tanto Sócrates quanto Zaratustra vão ao mercado. Esta atitude mostra que a virtude encontra-se em germe na alma da pessoa comum que pode desenvolvê-la. $\mathrm{O}$ virtuoso não é o herói ou o intelectual, mas a pessoa comum que orienta o seu agir na idéia de bem.

8. O título da principal obra de Aristóteles no campo da ética, a Ética a Nicômacos, por ser dirigida ao ser individual (seu filho) nos mostra o toque individualista da ética aristotélica.

9. Este é o título de um bem conhecido livro de Gilles Lipovetsky um dos mais importantes representantes do movimento ntelectual chamado pós-moderno.

10. Este outro de título de um dos livros de Lipovetsky: A era do vazio.

11. É preciso lembrar que se trata aqui de uma fase do pensamento de Lipovetsky em que ele se declara defensor das posições pós-modernas. Em fase mais recente, este mesmo autor faz uma reavaliação de seus posicionamentos anteriores. Particularmente, na sua obra Hiper-modernidade, afirma que, na verdade, não nos encontramos num período pós-, mas num período hiper-moderno, ou seja, a realidade que vivemos hoje, verdade, são formas radicalizadas de tendências já presentes na própria modernidade.

12. O próprio Habermas considera-se um membro da Escola de Frankfurt, se por isso se entender fazer filosofia crítica. Não se pertencer à Escola de Frankfurt significa concordar com todas as teses de seus mestres.

13. Há importantes diferenças entre estes autores que não são possíveis detalhar neste momento. Uma delas refere-se ao fato de que Apel admite e Habermas não um fundamento transcendental para os valores.

14. Segundo palavras de Habermas (1989, p. 149), "o princípio da Ética do Discurso proíbe que, em nome de uma autoridade filosófica, se privilegiem e se fixem de uma vez por todas numa teoria moral determinados conteúdos normativos".

Educ. Soc., Campinas, vol. 26, n. 92, p. 983-1011, Especial - Out. 2005

Disponível em <http://www.cedes.unicamp.br> 
Educação e valores no mundo contemporâneo

15. Esta concepção é comum tanto a Dewey, Piaget e Kohlberg e certamente também a Habermas. Todos estes autores estabeleceram níveis de desenvolvimento moral diferentes entre si, mas que, de certo modo, baseiam-se no mesmo princípio do desenvolvimento da personalidade moral. Não há espaço aqui para entrar em detalhes a respeito destas teorias. $\mathrm{Na}$ opinião de Piaget, por exemplo, há três fases de desenvolvimento moral, sendo que o primeiro é o nível pré-moral em que o sujeito ainda não tem o sentido da obrigação com relação ao respeito a regras. O segundo é o nível heteronômico, em que o sujeito obedece e é submisso às normas e à autoridade e, por último, o nível autônomo, em que o sujeito conhece, considera o papel e as conseqüências das normas e leis.

16. Terry Eagleton (1998, p. 9) lembra a respeito que "seria desonestidade intelectual fingir que o marxismo não representa mais uma realidade política atuante, ou que as perspectivas de mudança socialista, pelo menos neste momento, não passam de remotíssimas. Ocorre que, nestas circunstâncias, seria bem mais prejudicial que desonesto renunciar à visão de uma sociedade justa e, dessa forma, aquiescer à desordem pavorosa em que se encontra o mundo atual".

\section{Referências bibliográficas}

ABBAGnANO, N. Dicionário de filosofia. São Paulo: Mestre Jou, 1970.

BAUMAN, Z. Ética pós-moderna. Trad. João Resende Costa. São Paulo: Paulus, 1997.

CORTINA, A. O fazer ético. São Paulo: Moderna, 2003.

DURKHEIM, E. Ética e sociologia da moral. Trad. Paulo Castanheira. São Paulo: Landy, 2003.

EAGLETON, T. As ilusões do posmodernismo. Trad. Elisabeth Barbosa. Rio de Janeiro: J. Zahar, 1998.

GOERGEN, P. Pós-modernidade, ética e educação. Campinas: Autores Associados, 2005.

HABERMAS, J. Consciência moral e agir comunicativo. Trad. Guido A. de Almeida. Rio de Janeiro: Tempo Brasileiro, 1989.

HABERMAS, J. A ética da discussão e a questão da verdade. Trad. Marcelo Brandão Cipolla. São Paulo: Martins Fontes, 2004.

HELLER, A. et al. Uma crise da civilização: os desafios futuros. In: Heller, A. et al. A crise dos paradigmas em ciências sociais e os desafios para o século XXI. Rio de Janeiro: Contraponto, 1999. p. 13-32. 
KANT, I. Sobre a pedagogia. Trad. Francisco Cock Fontanella. Piracicaba: UNIMEP, 1996.

LALANDE, A. Vocabulário técnico e crítico de filosofia. São Paulo: Martins Fontes, 1999.

LIPOVETSKY, G. A era do vazio, ensaio dobre o individualismo contemporâneo. Lisboa: Relógio d'Água, 1983.

LIPOVETSKY, G. O crepúsculo do dever: a ética indolor dos novos tempos democráticos. Trad. Fátima Gaspar e Carlos Gaspar. Lisboa: Dom Quixote, 1994.

LIPOVETSKY, G. Os tempos hipermodernos. Trad. Mario Vilela. São Paulo: Barcarolla, 2004.

NIETZSCHE, F. Also sprach Zarathustra; Gesammelte Werke 7. München: Goldmann, s.d.

NIETZSCHE, F. Jenseits von Gut und Böse; Gesammelte Werke 8. München: Goldmann, s.d.

NIETZSCHE, F. Zur Genealogie der Moral; Gesammelte Werke 8. München: Goldmann, s.d.

PIEPER, A. Einführung in die Ethik. Tübingen: A. Francke, 2003.

PUIG, J.M. A construção da personalidade moral. São Paulo: Ática, 1998.

ROUSSEAU, J.J. Emilio ou Da educação. São Paulo: Bertrand Brasil, 1992.

ROUSSEAU, J.J. Contrato social. Lisboa: Presença, 1973.

SCHELER, M. Das Ressentiment im Aufbau der Moralen. Frankfurt: Vittorio Klostermann, 1978.

VATTIMO, G. Etica de la interpretación. Trad. José Luis Etcheverry. Buenos Aires: Paidos, 1992. 